\title{
Cometabolic Bioremediation
}

Terry C. Hazen

Lawrence Berkeley National Laboratory

Berkeley, California USA

TCHazen@Ibl.gov

\begin{abstract}
Cometabolic bioremediation is probably the most under appreciated bioremediation strategy currently available. Cometabolism strategies stimulate only indigenous microbes with the ability to degrade the contaminant and cosubstrate e.g. methane, propane, toluene and others. This highly targeted stimulation insures that only those microbes that can degrade the contaminant are targeted, thus reducing amendment costs, well and formation plugging, etc. Cometabolic bioremediation has been used on some of the most recalcitrant contaminants, e.g. PCE, TCE, MTBE, TNT, dioxane, atrazine, etc. Methanotrophs have been demonstrated to produce methane monooxygense, an oxidase that can degrade over 300 compounds. Cometabolic bioremediation also has the advantage of being able to degrade contaminants to trace concentrations, since the biodegrader is not dependent on the contaminant for carbon or energy. Increasingly we are finding that in order to protect human health and the environment that we must remediate to lower and lower concentrations, especially for compounds like endocrine disrupters, thus cometabolism may be the best and maybe the only possibility that we have to bioremediate some contaminants.
\end{abstract}

\section{Introduction}

Cometabolism is the process by which a contaminant is fortuitously degraded by an enzyme or cofactor produced during microbial metabolism of another compound. Typically, there is no apparent benefit to the microorganism involved. Bioremediation strategies that use electron donors that only stimulate a specific group of microorganisms that can degrade the contaminants of concern are ideal for many applications. Many electron donors used as amendments for bioremediation can broadly stimulate many members of the indigenous microbial community, most of which do not have the ability to degrade or completely degrade the contaminants of concern. Indeed, this often creates problems excess biomass (e.g. plugging the aquifer around the injection site), incomplete degradation of contaminants, transformation of 
contaminants to more recalcitrant or toxic daughter products, higher costs (amendment/contaminant), and inability of the amendment to stimulate biodegradation at low contaminant concentrations. Cometabolic bioremediation enables remediation strategies that stimulate biodegradation of the contaminants at contaminant concentrations that are way below the concentration that could be of carbon or energy benefit to the biodegrader. Thus cometabolic bioremediation has the added advantage of allowing scrubbing of environmental contaminants down to undetectable concentrations, e.g. < parts per trillion. Cometabolic bioremediation has been applied both aerobically and anaerobically to a wide variety of contaminants in different environments. The first mention of cometabolic bioremediation was by Wilson and Wilson (1985) and was later defined by McCarty (1987). Cometabolic bioremediation has been used in the field for more than 20 years on some of the most recalcitrant contaminants, e.g. chlorinated alkenes, PAHs, halogenated aliphatic and aromatic hydrocarbons, MTBE, explosives, dioxane, PCBs, and pesticides.

Microorganisms are versatile in their ability to exist in a variety of habitats and live in hostile environments having a wide range of $\mathrm{pH}$, temperature, heavy metal concentrations, oxygen concentrations, barometric pressures, salinity and radiation. Under these diverse conditions a number of microbial types have been isolated that cometabolize contaminants and their daughter products. Ensley (1991) demonstrated a linkage between TCE degradation and aromatic metabolism in $P$. cepacia $G 4, P$. mendocina and $P$. putida. Ensign et al. (1992) reported that pure cultures of Xanthobacter sp. cometabilized TCE with the utilization of propylene as a substrate using the enzyme alkene monooxygenase. It is well recognized that TCE and other chlorinated aliphatic compounds can be degraded by selected methanogens (Bouwer and McCarty, 1984), methanotrophs (Little et al., 1988), species of Pseudomonas (P. cepacia, P. mendocina and P. putida), and nitrifiers (Vannelli et al., 1990; Hyman et al., 1988) capable of degrading aromatic compounds (Nelson et al., 1988). Additionally, aerobic conditions do not appear to support the formation of undesirable metabolites, such as C-DCE, t-DCE or VC that are dehalogenation products of anaerobic degradation of TCE. Mahendra et al. (2007) demonstrated that monooxygenasecontaining bacteria could degrade 1,4-dioxane. Methyl tert-butyl ether (MTBE) has also been remediated cometabolically (Chen et al., 2006), as has TNT (Yasin et al., 2008), PCBs (Lajoie et al., 1994), and atrazine (Ghosh and Philip, 2004) (Figure 1).

The aerobic cometabolic biodegraders are dependent upon oxygenases, e.g. methane monooxygenase, toluene dioxygenase, toluene monooxygenase, and 
ammonia monooxygense. These enzymes are extremely strong oxidizers, e.g. methane monooxygenase is known to degrade over 300 different compounds. However, like any bioremediation process the proper biogeochemical conditions are necessary to maximize and maintain biodegradation, e.g. maintaining oxygen levels or other terminal electron acceptors that the cometabolic biodegrader is dependent on (Hazen, 1997 and Chapters this book on biostimulation and in situ groundwater bioremediation). In addition, co-metabolic biostimulation may require pulsing of electron donor or electron acceptor to reduce competitive inhibition between the substrate the microbe can use and the contaminant. Pulsing of methane was found to significantly improve biodegradation of TCE rates by methanotrophs (Hazen et al., 2009). It has also been found that significant background biodegradation reactions can occur during injection of terminal electron acceptors like oxygen. Enzien et al. (1994) demonstrated that in a bulk aerobic environment being injected with methane and air that significant amount of reductive dechlorination of PCE to TCE could occur in anaerobic niches in the aquifer sediment. Rates of PCE and TCE oxidation are inversely different depending on the number of $\mathrm{Cl}$ (Figure 2).

Given the diverse body of literature on cometabolic bioremediation processes we will focus in detail on the two groups that have been most well studied, i.e. methanotrophs and ammonium oxidizers.

\section{Methanotrophs}

Methanotrophs, methane-oxidizing bacteria, oxidize methane via a series of enzymes that are unique to this group (Koh et al. 1993). The primary enzyme in this oxidation chain is methane monooxygenase. Methane monooxygenase is an extremely powerful oxidizer, thus giving it the capability of oxidizing a wide variety of normally recalcitrant compounds including TCE (Cardy et al., 1991). Wackett (Newman and Wackett, 1991; Tsien et al., 1989) and others (Chaudhry and Chapalamadugu, 1991; Wilson and Wilson, 1985; Fogel et al., 1986; Little et al., 1988) demonstrated that soluble methane monooxygenase induces formation of TCE-epoxide from TCE. TCEepoxide is extremely unstable and therefore spontaneously breaks down to simpler compounds like formate, etc. All of the daughter compounds are either unstable or small and easily metabolizable compounds, thus making the final and almost immediate end products of TCE-epoxide formation, carbon dioxide and chloride salts, unlike anaerobic dechlorination which can stall at daughter products like vinyl chloride which are more toxic than the original contaminant, e.g. PCE and TCE (Figure 3). 
Methanotrophic bacteria (methanotrophs) are bacteria that use methane as a sole source of carbon. The first enzyme involved in the oxidation of methane to methanol by methanotrophs is methane monooxygenase (MMO). Two forms of MMO have been reported. Soluble methane monooxygenase (SMMO), found mainly in the cytoplasm and particulate methane monooxygenase (pMMO) which is associated with the cell membrane. Studies related to these two enzymes have mainly been studied in two methanotrophs namely, Methylococcus capsulate (Bath) and Methylococcus trichosporium OB3b. Numerous groups have studied SMMO in great detail with regard to isolation and characterization as well as crystal structure. Since pMMO is membrane bound this enzyme losses activity upon lysis making it difficult to isolate and purify resulting in fewer details regarding this enzyme. The two enzymes can co-exist in methanotrophs; however, their activities have been directly reported to be dependent on the copper ion to biomass ratio in M. capsulate (Bath). A low copper ion to biomass ratio expresses SMMO while a high copper ion to biomass ratio expresses $\mathrm{pMMO}$ (Stanley et al. 1983). While pMMO is found in most methanotrophic bacteria sMMO is present only in a few select methanotrophs. Both MMOs oxidize methane to methanol and are capable of co-metabolizing chlorinated aliphatic hydrocarbons namely, chloroform, dichloromethane, trans-dichloroethene, cis-1,2-dichloroethene, 1,1dichloroethene, trichloroethene at various rates and to different extents. Therefore, methanotrophs are a useful tool for commercial purposes mainly clean-up of sites contaminated with toxic pollutants. However, sMMO being non-specific has a broader substrate specificity in comparison to $\mathrm{pMMO}$, some substrates like cyclohexane or naphthalene cannot be oxidized by $\mathrm{pMMO}$, and both enzymes do not oxidize perhloroethylene. Methanotrophs have also been reported to be useful for production of bulk chemicals and as methane sinks (Oremland and Culbertson, 1992). Mixed cultures expressing pMMO have shown to degrade t-DCE, VC, C-DCE, TCE and 1,1DCE. Transformation of t-DCE and VC by pMMO was 20 times greater than those reported for SMMO, while transformation of the other three compounds was either similar or less indicating the importance of this enzyme over SMMO for bioremediation.

One of the many uses of methanotrophs has been in the bioremediation of trichloroethylene (TCE), which is most commonly found in groundwater along with other halogenated compounds. The first product formed in the oxidation of TCE is an epoxide which is then converted to glyoxylic acid with chloride being released. Glyoxylic acid is then oxidized to carbon dioxide. Although TCE is known to be degraded by several other bacteria e.g., various species of Pseudomonas, containing oxygenases, the rate 
of degradation by methanotrophs expressing $\mathrm{SMMO}$ is many times faster than $\mathrm{pMMO}$ and other oxygenases making it favorable for use in bioremediation. For efficient bioremediation it is important to optimize enzyme/enzymes activity responsible for the transformation, as well as to maintain the activity for extended period of time. This has been studied in detail for M. trichosporium OB3 by Sayler et al. (1995). Their study showed that specific SMMO activity was directly proportional to the concentration of dissolved methane. Addition of formate, $(20 \mathrm{mM})$, significantly increased sMMO activity. Nitrate, phosphate, iron and magnesium also had remarkable effect on growth as well as SMMO activity. Addition of vitamins also effected SMMO activity however, excessive vitamins proved to be harmful. Such studies are necessary and prove useful when designing a bioremediation process.

sMMO from M. capsulatus (Bath) and M. trichosporium OB3b was shown to consist of three components: protein A, a hydroxylase made-up of three subunits $\alpha, \beta, \gamma$, of molecular masses 60,45 , and $20 \mathrm{kDa}$ respectively, protein $\mathrm{B}$ which is $16 \mathrm{kDa}$, a regulatory protein and protein C $39 \mathrm{kDa}$, a reductase (Paulsen et al., 1994). The crystal structure of SMMO hydroxylase has also been determined (Rosenzweig et al. 1993) (Figures 4 and 5). In both organisms, the genes encoding for soluble methane monooxygenase enzyme complexes have been found to be clustered on the chromosome. The complete DNA sequences of both gene clusters have been determined and they show considerable homology (Murrell 1992). Detailed studies of the genes encoding SMMO, the DNA sequence has led to the development of SMMO probes which have been used to detect MMO gene-specific DNA and methanotrophs in mixed cultures and in natural environmental samples (Hazen et al., 2009). The genes for Protein B and Protein C of Methylococcus have been expressed in E. coli and the proteins obtained were functionally active. Cloning of SMMO genes has led to construction of SMMO mutants of $M$. trichosporium OB3b.

Anderson and McCarty (1997) have reported higher yields of t-DCE and VC degradation by methanotrophs expressing pMMO as compared to SMMO. Also the fact that pMMO are present in most methanotrophs, it seems logical to develop systems that can enhance this activity for the purpose of treatment of sites contaminated with these compounds. Although sMMO and pMMO are known to co-exist in methanotrophs, the fact that $\mathrm{pMMO}$ is membrane bound has made it difficult to purify this enzyme unlike SMMO and perform detailed studies like SMMO. Several groups have attempted and are still pursuing this aspect of pMMO and to date only a few reports are available. 
Isolation of active pMMO from methanotrophs has been difficult since it loses activity once it has been separated from the membrane. The loss of pMMO activity has been reported to be overcome by addition of a non-ionic detergent followed by removal of the detergent and reconstitution of lipid vesicle. Activity of pMMO in the membrane fraction was also stabilized by increasing the concentration of copper in growth medium. Other factors favoring $\mathrm{pMMO}$ activity were, increased iron and copper concentration, maintaining the $\mathrm{pH}$ of buffer at 7.0 and anaerobic conditions during solublization . Addition of copper ions has resulted in enhanced pMMO activity however, it has not prolonged the activity nor does it reactivate the enzyme once activity is lost (Zahn et al., 1996). The isolation and characterization of $\mathrm{pMMO}$ from $M$. capsulatus (Bath) has been reported by Nguyen et. al. (1998) They have obtained active stable pMMO from $M$. capsulatus (Bath) by maintaining high copper levels and methane stress conditions in growth medium. Membrane solublization was achieved under anaerobic conditions and addition of dodecyl beta-D-maltoside. The active extract was then purified by chromatography. By switching the growth conditions to favor pMMO activity over sMMO the same group has reported three polypeptides of 46, 35, $26 \mathrm{kDA}$ and has shown a trinuclear copper centre in $\mathrm{pMMO}$ by EPR. They have reported pMMO to be copper requiring and sensitive to dioxygen similar to the results of Zahn et al. (1996). The switch between SMMO and pMMO gene expression has been suggested to involve a common regulatory. Recent report by Chan et al. (2004), has shown pMMO from $M$. capsulatus (Bath) to be a copper-containing three-subunit enzyme. The role of copper in $\mathrm{pMMO}$ has been reported to be in the active site of $\mathrm{pMMO}$ rather than a structural one.

\section{Ammonium Oxidizers}

Nitrification is the bacterial mediated process in which ammonia is oxidized sequentially to nitrite then to nitrate. In soils and fresh and saline waters, ammonia is oxidized to nitrite by nitrite-oxidizing bacteria such as the chemolithoautotrophic bacterium, Nitrosomonas europaea. Nitrite is oxidized to nitrate by nitrate-oxidizing bacteria such as Nitrobacter agilis and N. winogradskyi (Fliermans et al., 1974). Nitrifying bacteria are ubiquitous components of the soil and sediment microbial populations. Their activities are stimulated in agricultural soils following the application of ammonia or urea based fertilizers.

The oxidation of ammonia to nitrite by Nitrosomonas europaea is initiated by the enzyme, ammonia monooxygenase (AMO). Because of the broad substrate range of 
AMO (Arciero et al., 1989), nitrifiers such as N. europaea can be used in the bioremediation of contaminated soils, sediments and groundwaters (Yang et al., 1999). AMO catalyzes the oxidation of ammonia to hydroxylamine with is subsequently oxidized to nitrite ( $\mathrm{NO}_{2}$ ) by hydroxylamine oxidoreductase (Wood, 1986) with the release of four electrons. Two of the electrons are transferred to AMO in order to activate the $\mathrm{O}_{2}$ and maintain a steady state for ammonia oxidation. AMO in Nitrosomonas europaea also catalyzes the oxidation of several alternate substrates including hydrocarbons and halogenated hydrocarbons (Rasche et al., 1990). These oxidations require a reductant which can be supplied by the simultaneous oxidation of ammonia.

Both $\mathrm{CH}_{4}$ and $\mathrm{C}_{2} \mathrm{H}_{4}$ competitively inhibit ammonia oxidation by $N$. europaea, since it appears that these compounds bind predominantly to the same binding site as ammonia (Keener and Arp, 1993). The competitive character of the inhibition of $\mathrm{CH}_{4}$, $\mathrm{C}_{2} \mathrm{H}_{4}, \mathrm{C}_{2} \mathrm{H}_{6}, \mathrm{CH}_{3} \mathrm{Cl}$, and $\mathrm{CH}_{3} \mathrm{Br}$ is supported by the optimal $\mathrm{N}_{2} \mathrm{H}_{4}$ requirements that decrease with increasing concentrations of ammonia. Thus it is not likely that the stimulation of TCE degrading bacteria of the genus Nitrosomonas would occur with the injection of methane or other substrates that were competitively inhibitory to the AMO enzyme. Under bioremediation techniques that injected methane, a loss of the Nitrosomonas population that has the ability to degrade TCE would be inhibited. Such a phenomenon was observed through the use of species-specific fluorescent antibodies (Fliermans et al., 1994; Hazen et al., 1994).

A movie which can be downloaded at http://esd.Ibl.gov/people/thazen/Videos/MMO\%20Movie.mpg shows how methane monooxyengase interacts with TCE to form TCE-epoxide which spontaneously breaks down to $\mathrm{CO} 2$ and $\mathrm{Cl}$.

\section{Research Needs}

Cometabolic bioremediation is extremely under appreciated as a bioremediation strategy, though it has been used for an extremely wide variety of contaminants in different environments with different cosubstrates. Much more research needs to be done on modeling life cycle costs of various remediation strategies, including treatment trains and grading into natural attenuation or intrinsic bioremediation. These models need to be tested and verified in full-scale deployments. Cometabolic processes quite 
often can easily be graded into natural attenuation, e.g. air injection alone at sites with methane or other cometabolic substrate to increase degradation rate and transition into a stable aerobic or microaerophilic environment that can sustain natural attenuation of any residual contaminant. Research on bioaugmentation strategies using cometabolic biodegraders and synthetic biology to produce unique, high rate and highly specific biodegraders could vastly improve our environmental stewardship in the future.

\section{Acknowledgment}

The work reflected here was partially supported by the U.S. Department of Energy under Contract No. DE-AC02-05CH11231.

\section{References}

Anderson, J. E., and P. L. McCarty. 1997. Transformation yields of chlorinated ethenes by a methanotrophic mixed culture expressing particulate methane monooxygenase. Appl. Environ. Microbiol. 63:687-693.

Arciero, D.M., T. Vannelli, M. Logan and A.B. Hooper. 1989. Degradation of Trichloroethylene by the ammonia-oxidizing bacterium, Nitrosomonas europaea. Biochem. Biophys. Res. Commun. 159:640-643.

Bouwer, E. J. and P. L. McCarty. 1984. Modeling of trace organics biotransformation in the subsurface. Ground Water 22:433-440.

Cardy, D. N. L., V. Laidler, G. P. C. Salmond and J. C. Murrell. 1991. Molecular analysis of the methane monooxygenase (MMO) gene cluster of Methylosinus trichosporium OB3b. Mol. Microbiol. 5: 1261-1264.

Chan, S. I., K. H. C. Chen, S. S. F. Yu, C. L. Chen, and S. S. J. Kuo. 2004. Toward delineating the structure and function of the particulate methane monooxygenase from methanotrophic bacteria. Biochemistry 43:4421-4430.

Chaudhry, G. R., and S. Chapalamadugu. 1991. Biodegradation of Halogenated Organic-Compounds. Microbiological Reviews 55:59-79.

Chen, K. F., C. M. Kao, T. Y. Chen, C. H. Weng, and C. T. Tsai. 2006. Intrinsic bioremediation of MTBE-contaminated groundwater at a petroleum-hydrocarbon spill site. Environmental Geology 50:439-445.

Ensley, B.D. 1991. Biochemical diversity of trichloroethylene metabolism. Annu. Rev. Microbiol. 45: 283-299.

Ensign, S. A., M. R. Hyman and D. J.Arp. 1992 Cometabolic degradation of chlorinated alkenes by alkene monooxygenase in a propylene-grown Xanthobacter strain. Appl. Enviorn. Microbiol. 58: 3038-3046.

Enzien, M. V., F. Picardal, T. C. Hazen, R. G. Arnold, and C. B. Fliermans. 1994. Reductive dechlorination of trichloroethylene and tetrachloroethylene under aerobic conditions in a sediment column. Appl. Environ. Microbiol. 60:22002205.

Fliermans, C.B., B.B. Bohlool and E.L. Schmidt. 1974. Detection of Nitrobacter in natural habitats using fluorescent antibodies. Appl. Microbiol. 27: 124-129.

Fliermans, C.B., J.M. Dougherty, M.M. Franck, P.C. McKinsey and T. C. Hazen. 1994. Immunological Techniques as Tools to Characterize the Subsurface Microbial Community at a Trichloroethylene Contaminated Site. In: Applied Biotechnology 
for Site Remediation eds. R. E. Hinchee, et al. Lewis Publishers. Boca Raton, FL. pgs 186-203.

Fogel, M. M., A. R. Taddeo, and S. Fogel. 1986. Biodegradation of chlorinated ethenes by a methane-utilizing mixed culture. Appl. Environ. Microbiol.^t51 720-724.

Ghosh, P. K., and L. Philip. 2004. Atrazine degradation in anaerobic environment by a mixed microbial consortium. Water Research 38:2277-2284.

Hazen, T. C., R. Chakraborty, J. Fleming, I. R. Gregory, J. P. Bowman, L. Jimenez, D. Zhang, S. M. Pfiffner, F. J. Brockman, and G. S. Sayler. 2009. Use of gene probes to assess the impact and effectiveness of aerobic in situ bioremediation of TCE. Archives Of Microbiology 191:221-232.

Hazen, T. C., K. H. Lombard, B. B. Looney, M. V. Enzien, J. M. Dougherty, C. B. Fliermans, J. Wear, and C. A. Eddy-Dilek. 1994. Summary of In Situ Bioremediation Demonstration (Methane Biostimulation) Via Horizontal Wells at the Savannah River Site Integrated Demonstration Project. Proceedings ThirtyThird Hanford Symposium on Health and the Environment: In-Situ Remediation: Scientific Basis for Current and Future Technologies, p. 135-150 G. W. Gee and N. R. Wing (eds). Battelle Press, Columbus, OH.

Hazen, T. C. 1997. Bioremediation, p. 247-266. In P. A. a. D. Haldeman (ed.), Microbiology of the Terrestrial Subsurface. CRC Press, Boca Raton.

Hyman, M. R., I. B. Murton, and D. J. Arp. 1988. Interactions of ammonia monoxygenase from Nitrosomonas europaea with alkanes, alkenes and alkynes. Appl. Environ. Microbiol. 54: 3187-3190.

Keener, W. K. and D. J. Arp. 1993. Kinetic studies of ammonia monooxygenase inhibition in Nitrosomonas europaea by hydrocarbons and halogenated hydrocarbons in an optimized whole-cell assay.

Koh, S.-C., J. P. Bowman, and G. S. Sayler. 1993. Soluble methane monooxygenase production and trichloroethylene degradation by a type I methanotroph, Methlomonas methanica 68-1. Appl. Environ. Microbiol. 59:960-967.

Lajoie, C. A., A. C. Layton, and G. S. Sayler. 1994. Cometabolic Oxidation of Polychlorinated-Biphenyls in Soil with a Surfactant-Based Field Application Vector. Applied And Environmental Microbiology 60:2826-2833.

Little, C. D., A. V. Palumbo, S. E. Herbes, M. E. Lidstrom, R. L. Tyndall and P. L. Gilmer. 1988. Trichloroethylene biodegradation by a methane-oxidizing bacterium. Appl. Environ. Microbiol. 54:951-956.

Mahendra, S., C. J. Petzold, E. E. Baidoo, J. D. Keasling, and L. Alvarez-Cohen. 2007. Identification of the intermediates of in vivo oxidation of 1,4-dioxane by monooxygenase-containing bacteria. Environmental Science \& Technology 41:7330-7336.

McCarty, P. L. 1987. Bioengineering issues related to in situ remediation of contaminated soils and groundwater, p. 143-162. In G. S. Omenn (ed.), Environmental Biotechnology. Plenum Press, New Your, N. Y.

Murrell, J.C. 1992. The genetics and molecular biology of obligate methane-oxidizing bacteria, p. 115-148. In: J.C. Murrell and H. Dalton (ed.), Methane and methanol utilizers. Plenum Press, New York.

Nelson, M. J. K., S. O. Montgomery and P. H. Prichard. 1988. Trichloroethylene metabolism by microorganisms that degrade aromatic compounds. Appl. Environ. Microbiol. 54: 604-606.

Newman, L. M., and L. P. Wackett. 1991. Fate of 2,2,2-Trichloroacetaldehyde (Chloral Hydrate) Produced during Trichloroethylene Oxidation by Methanotrophs. Appl. Environ. Microbiol. 57:2399-2402.

Nguyen, H. H. T., S. J. Elliott, J. H. K. Yip, and S. I. Chan. 1998. The particulate methane monooxygenase from Methylococcus capsulatus (Bath) is a novel 
copper-containing three-subunit enzyme - Isolation and characterization. Journal of Biological Chemistry 273:7957-7966.

Oremland, R. S., and C. W. Culbertson. 1992. Importance of Methane-Oxidizing Bacteria in the Methane Budget as Revealed by the Use of a Specific Inhibitor. Nature 356:421-423.

Paulsen, K. E., Y. Liu, B. G. Fox, J. D. Lipscomb, E. Munck, and M. T. Stankovich. 1994. Oxidation-Reduction Potentials of the Methane Monooxygenase Hydroxylase Component from Methylosinus trichosporium Ob3b. Biochemistry 33:713-722.

Rasche, M. E., R. E. Hicks, M. R. Hyman, and D. J. Arp. 1990. Oxidation of monohalogenated ethanes and n-chlorinated alkanes by whole cells of Nitosomonas europaea. J. Bacteriol. 172: 5368-5373.

Rosenzweig, A. C., C. A. Frederick, S. J. Lippard, and P. Nordlund. 1993. CrystalStructure of a Bacterial Nonheme Iron Hydroxylase That Catalyzes the Biological Oxidation of Methane. Nature 366:537-543.

Sayler, G. S., A. Layton, C. Lajoie, J. Bowman, M. Tschantz, and J. T. Fleming. 1995. Molecular site assessment and process monitoring in bioremediation and natural attenuation. Applied Biochemistry and Biotechnology 54:277-290.

Tsien, H. C., G. A. Brusseau, R. S. Hanson, and L. P. Wackett. 1989. Biodegradation of trichloroethylene by Methylosinus trichosporium ob3b. Appl. Environ. Microbiol. 55:3155-3161.

Vannelli, T., M. Logan, D. Arciero and A. B. Hooper. 1990. Degradation of halogentaed aliphatics by the ammonia-oxidizing bacterium Nitrosomonas europaea. Appl. Environ. Microbiol. 56: 1169-1171.

Wilson, J. T. and B. H. Wilson. 1985. Biotransforamtion of trichloroethylene in soil. Appl. Environ. Microbiol. 29:242-243.

Wood, P.M. 1986. Nitrification as a bacterial energy source, p. 39-62. In: J.I. Prosser (ed), Nitrification. Society for General Mcirobiology (IRL Press), Washington, D.C.

Yang, L., Y. F. Chang, and M. S. Chou. 1999. Feasibility of bioremediation of trichloroethylene contaminated sites by nitrifying bacteria through cometabolism with ammonia. Journal of Hazardous Materials 69:111-126.

Yasin, M., A. A. Shah, A. Hameed, S. Ahmed, and F. Hasan. 2008. Use of microorganisms for the treatment of trinitrotoluene (TNT) containing effluents. Journal of the Chemical Society of Pakistan 30:442-448.

Zahn, J. A., D. M. Arciero, A. B. Hooper, and A. A. DiSpirito. 1996. Cytochrome c' of Methylococcus capsulatus Bath. European Journal of Biochemistry 240:684-691.

\section{Figure Legends}

Figure 1. Cometabolic bioremediation substrates, enzymes, contaminants

Figure 2. Aerobic and anaerobic biodegradation rates

Figure 3. Aerobic and anaerobic cometabolic pathways. 
Figure 4. Methane Monooxgenase 3D Molecular Structure.

Figure 5. MMO reaction site. 


\section{Figure 1. Cometabolic bioremediation substrates, enzymes, contaminants}

\begin{tabular}{|c|c|c|c|c|c|}
\hline Cosubstrates & $\begin{array}{l}\text { Methane, } \\
\text { Methanol, } \\
\text { Propane, } \\
\text { Propylene } \\
\text { (aerobic) }\end{array}$ & $\begin{array}{l}\text { Ammonia, } \\
\text { Nitrate } \\
\text { (aerobic) }\end{array}$ & $\begin{array}{l}\text { Toluene, butane, } \\
\text { phenol, citral, } \\
\text { cumin aldehyde, } \\
\text { cumene, and } \\
\text { limonene } \\
\text { (aerobic) }\end{array}$ & $\begin{array}{l}\text { Methanol } \\
\text { (anaerobic) }\end{array}$ & $\begin{array}{l}\text { Glucose, } \\
\text { Acetate, Lactate, } \\
\text { Sulfate, } \\
\text { Pyruvate } \\
\text { (anaerobic) }\end{array}$ \\
\hline $\begin{array}{l}\text { Enzymes } \\
\text { (microbes) }\end{array}$ & $\begin{array}{l}\text { Methane } \\
\text { Monooxygenase, } \\
\text { Methanol } \\
\text { Dehydrogenase, } \\
\text { Alkene } \\
\text { monooxygenase, } \\
\text { catechol } \\
\text { dioxygenase } \\
\text { (Methylosinus) }\end{array}$ & $\begin{array}{l}\text { Ammonia } \\
\text { Monooxygenase } \\
\text { (Nitrosomonas, } \\
\text { Nitrobacter) }\end{array}$ & $\begin{array}{l}\text { Toluene } \\
\text { Monooxygenase, } \\
\text { Toluene } \\
\text { Dioxygenase } \\
\text { (Rhodococcus, } \\
\text { Pseudomonas, } \\
\text { Arthrobacter) }\end{array}$ & $\begin{array}{l}\text { Alcohol } \\
\text { Dehydrogenases } \\
\text { (Pseudomonas, } \\
\text { Streptomyces, } \\
\text { Corynebacterium } \\
\text { ) }\end{array}$ & $\begin{array}{l}\text { Dehalogenase, } \\
\text { AtzA, } \\
\text { Dichloromethane } \\
\text { Dehalogenase } \\
\text { (Dehalococcoides } \\
\text {, Methanogens, } \\
\text { Desulfovibrio, } \\
\text { Clostridium, } \\
\text { Geobacter, } \\
\text { Clavibacter) }\end{array}$ \\
\hline Contaminants & $\begin{array}{l}\text { TCE, DCE, VC, } \\
\text { PAHs, PCBs, } \\
\text { MTBE, creosote, } \\
\text { >300 different } \\
\text { compounds }\end{array}$ & $\begin{array}{l}\text { TCE, DCE, VC, } \\
\text { TNT }\end{array}$ & $\begin{array}{l}\text { TCE, DCE, VC, } \\
\text { 1,1-DCE, 1,1,1- } \\
\text { TCA, MTBE }\end{array}$ & $\begin{array}{l}\text { PCE, TCE, DCE, } \\
\text { VC, Hexachloro- } \\
\text { cyclohexane }\end{array}$ & $\begin{array}{l}\text { BTEX, PCE, } \\
\text { PAHs, Pyrene, } \\
\text { Atrazine, TNT, } \\
\text { etc. }\end{array}$ \\
\hline
\end{tabular}


Relative Rates of Chlorinated -VOC Biodegradation

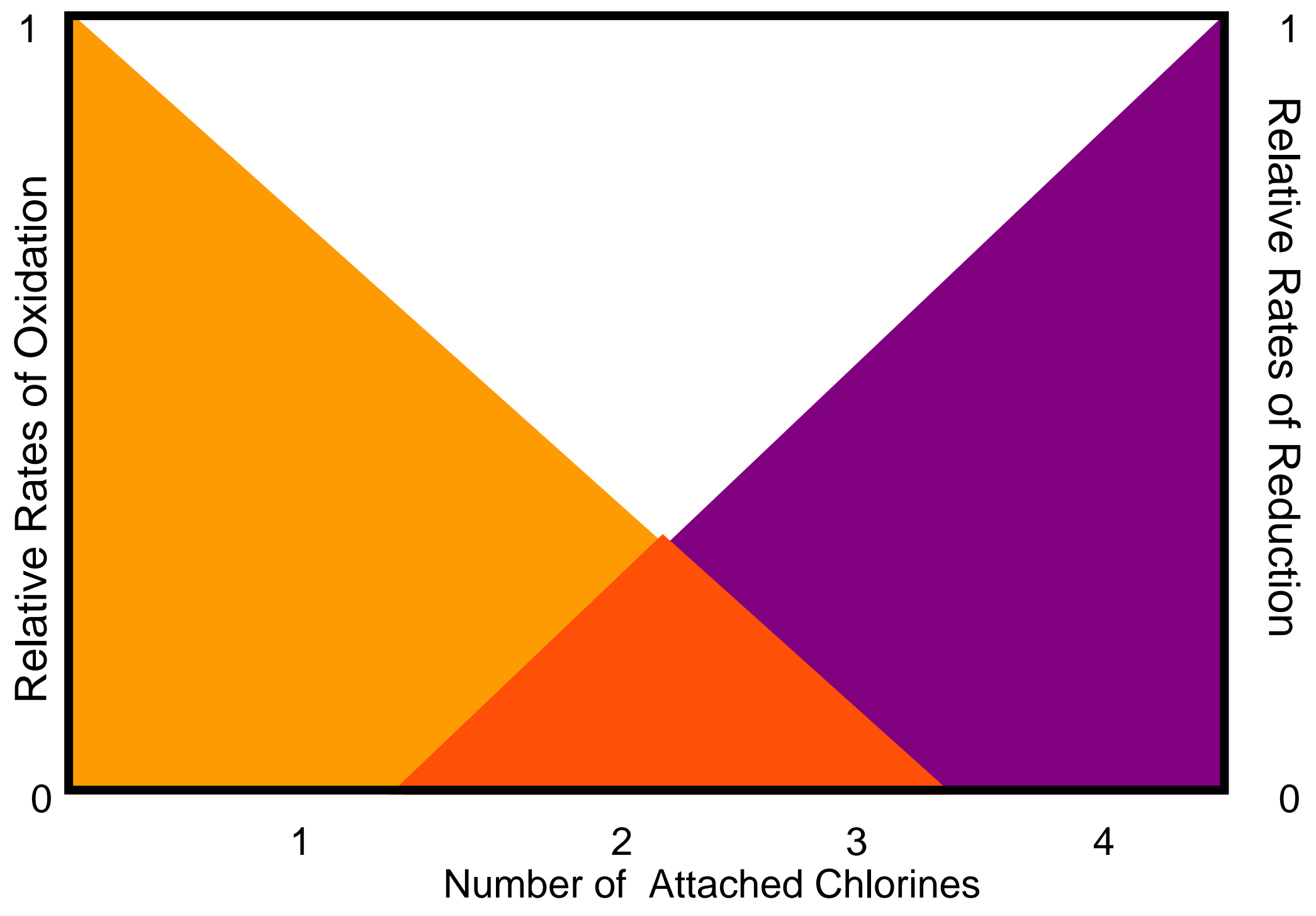




\section{Oxidative Degradation}

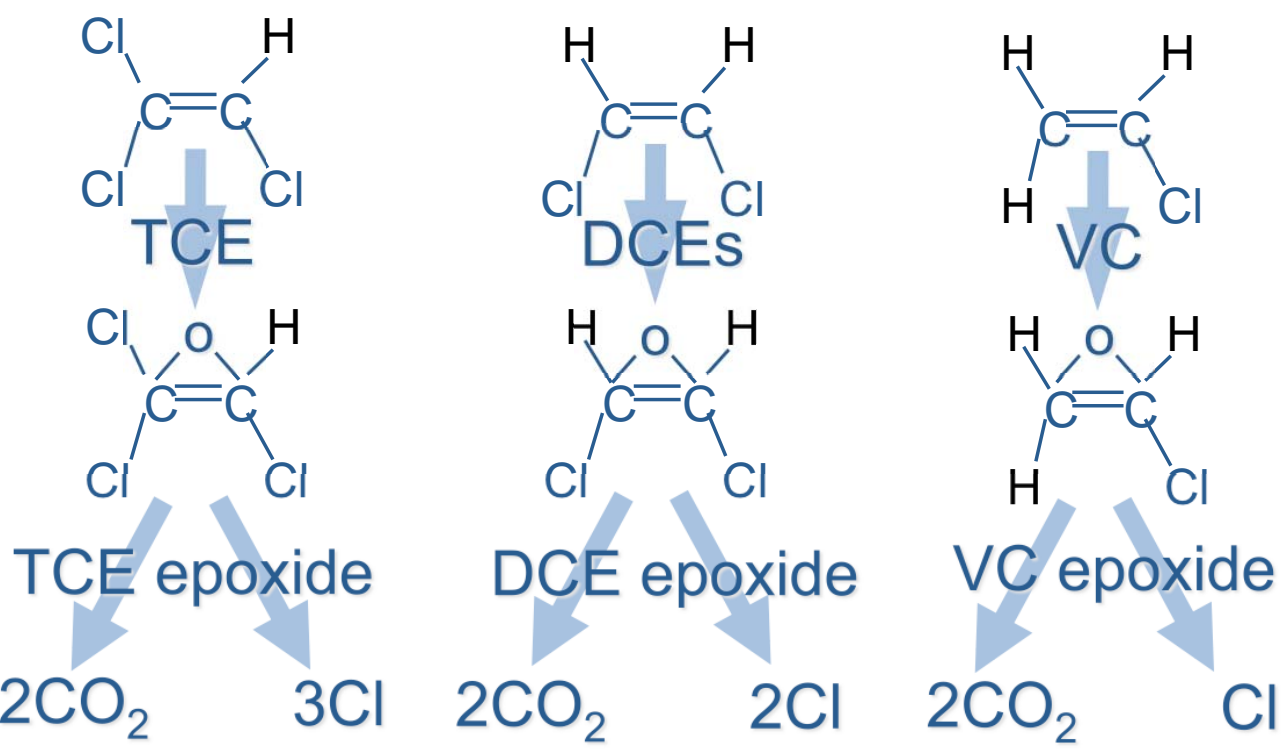

\section{Anaerobic reductive dechlorination}

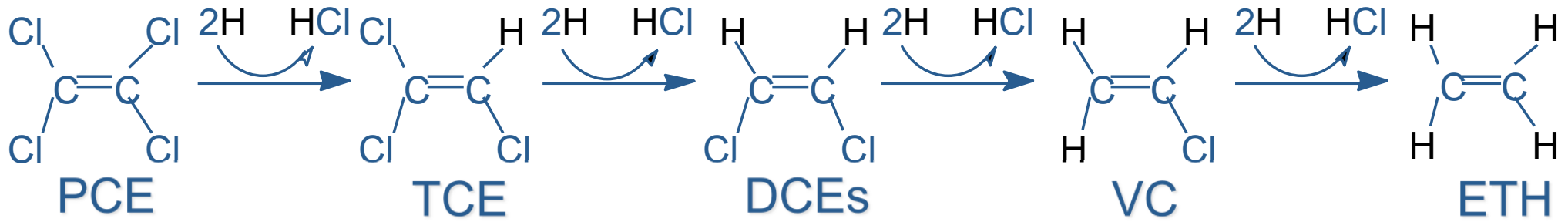




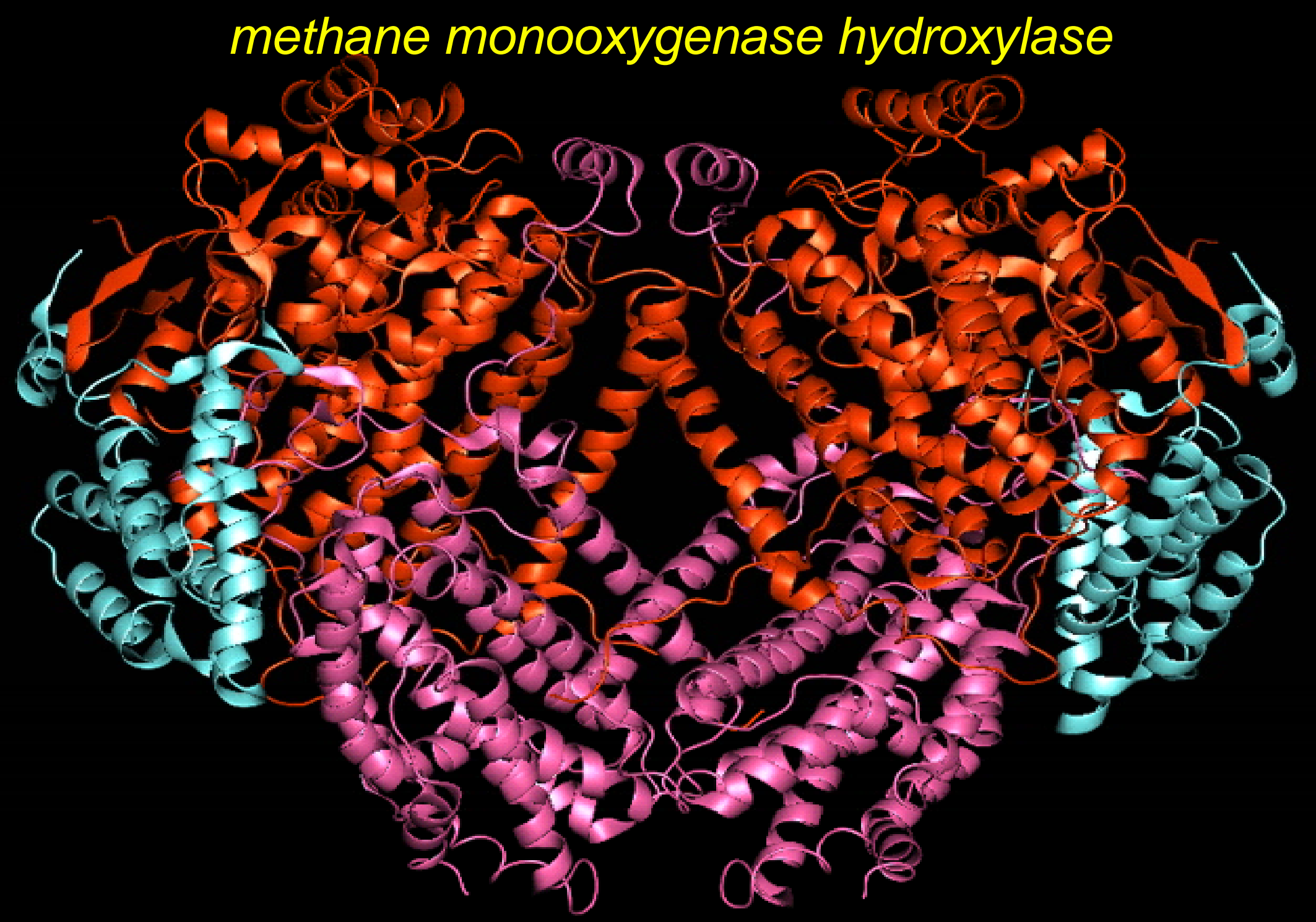

The MMO structure is a dimer of $\alpha$ (orange), $\beta$ (purple) and $\gamma$ (aqua) protein $\alpha$ carbon protein 
